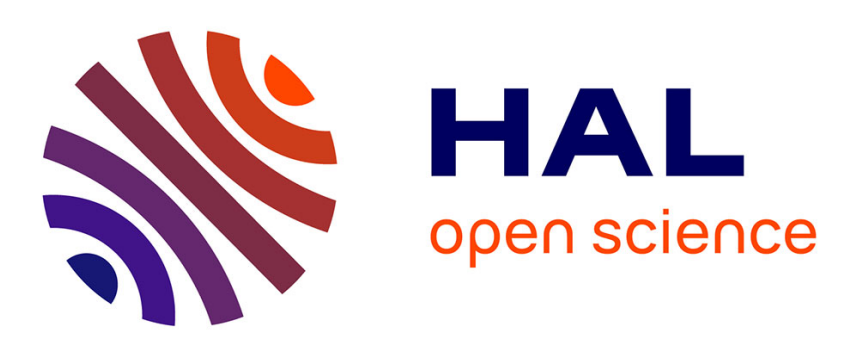

\title{
Dairy propionibacteria as human probiotics: A review of recent evidence
}

\author{
Fabien J. Cousin, Denis D G Mater, Benoît Foligné, Gwénaël Jan
}

\section{To cite this version:}

Fabien J. Cousin, Denis D G Mater, Benoît Foligné, Gwénaël Jan. Dairy propionibacteria as human probiotics: A review of recent evidence. Dairy Science \& Technology, 2011, 91 (1), pp.1-26. $10.1051 /$ dst/2010032 . hal-00868601

\section{HAL Id: hal-00868601 https://hal.science/hal-00868601}

Submitted on 16 Oct 2013

HAL is a multi-disciplinary open access archive for the deposit and dissemination of scientific research documents, whether they are published or not. The documents may come from teaching and research institutions in France or abroad, or from public or private research centers.
L'archive ouverte pluridisciplinaire HAL, est destinée au dépôt et à la diffusion de documents scientifiques de niveau recherche, publiés ou non, émanant des établissements d'enseignement et de recherche français ou étrangers, des laboratoires publics ou privés. 


\title{
Dairy propionibacteria as human probiotics: A review of recent evidence
}

\author{
Fabien J. Cousin • Denis D. G. Mater • \\ Benoît Foligné • Gwénaël Jan
}

Received: 3 November 2009 /Revised: 29 April 2010/Accepted: 29 April 2010 /

Published online: 2 August 2010

(C) INRA, EDP Sciences, 2010

\begin{abstract}
Probiotics have been the subject of intensive research, mainly focusing on bifidobacteria and lactic acid bacteria. However, there is evidence that dairy propionibacteria also display probiotic properties, which as yet have been underestimated. The aim of this paper is to review recent data which report probiotic characteristics of dairy propionibacteria and to distinctly organise them based on the experimental strategy employed: ranked from in vitro evidence to in vivo trials, which is a new approach. In addition to the selection criteria for probiotics in areas such as food safety, technological and digestive stress tolerance, many potential health benefits have been described which include modulation of microbiota and metabolic activity in the gut, modulation of intestinal motility and absorption, impact on intestinal inflammation, modulation of the immune system and potential modulation of risk factors for cancer development. The robust nature of dairy propionibacteria towards technological stresses should allow their future use in various fermented probiotic foods. Among the probiotic properties of dairy propionibacteria described in the literature, some of these properties are different from those reported for bifidobacteria and lactic acid bacteria. However, supplementation with dairy propionibacteria in randomised, placebo-controlled, double-
\end{abstract}

This article should be cited as: Cousin F.J. et al., Dairy propionibacteria as human probiotics: A review of recent evidence, Dairy Science \& Technology (2010), doi:10.1051/dst/2010032

F. J. Cousin • G. Jan $(\bowtie)$

INRA, UMR1253 Science et Technologie du Lait et de l'Oeuf, 35042 Rennes, France

e-mail: gwenael.jan@rennes.inra.fr

F. J. Cousin · G. Jan

AGROCAMPUS OUEST, UMR1253 Science et Technologie du Lait et de l'Oeuf,

35042 Rennes, France

F. J. Cousin • D. D. G. Mater

CNIEL/Syndifrais, 42 rue de Châteaudun, 75314 Paris 09, France

B. Foligné

Institut Pasteur de Lille, Bactéries Lactiques \& Immunité des Muqueuses, Centre d'Infection et d'Immunité de Lille, Unit 1019-UMR 8204, Univ. Lille Nord de France, 59019 Lille, France 
blind human trials has mainly involved mixtures of propionibacteria with probiotic bacteria from other genera. Clinical studies involving the use of dairy propionibacteria alone are lacking. Such studies will allow the specifically observed health benefits to be attributed to dairy propionibacteria. This, in turn, will allow the investigation of the synergistic effects with other probiotic bacteria or beneficial food components.

摘要 益生性丙酸菌的研究进展。近年来关于双歧杆菌和乳酸菌的益生性得到 了广泛的关注、相关的研究报道较多。尽管乳中的丙酸菌也显示具有益生菌 的功能、但并没有引起人们的重视。本文综述了近年来关于乳源丙酸菌益生 功能的研究进展。论述的内容包括从食品安全性考虑益生菌的选择标准、益 生菌的消化极限; 以及益生菌潜在的功能性、如对肠道中微生物菌群和代谢 活性的调整作用、促进肠道蠕动和吸收作用、对肠炎的作用、对免疫系统的 调节作用以及潜在的对癌症因子抑制作用。丙酸菌在乳中生产旺盛、因此从 技术层面上分析丙酸菌可以用于各种发酵食品。在关于乳源丙酸菌益生功能 性的文献报 道中、丙酸菌的一些功能性不同于双歧杆菌和乳酸菌。然而、在 双目失明的人体试验中、则是将来源于其他属的丙酸菌与乳源丙酸菌混合使 用。在临床试验中通常用含丙酸菌的乳制品和不含丙酸菌的乳制品同时进行 试验、目的是证明乳源丙酸菌对人体健康 的作用。同样方法也可以调查丙酸 菌与其他益生菌或食物中其他有益成分的协同作用。

Keywords Probiotic $\cdot$ Propionibacteria Propionibacterium $\cdot$ Short-chain fatty acid

关键词 益生性·丙酸菌 ·丙酸杆菌属 · 短链脂肪酸

$\begin{array}{ll}\text { Abbreviations } \\ \text { ACNQ } & \text { 2-amino-3-carboxy-1,4- naphthoquinone } \\ \text { AEDS } & \text { Atopic eczema-dermatitis syndrome } \\ \text { BGS } & \text { Bifidogenic growth stimulator } \\ \text { CLA } & \text { Conjugated linoleic acid } \\ \text { CMA } & \text { Cow's milk allergy } \\ \text { CRP } & \text { C-reactive protein } \\ \text { DHNA } & \text { 1,4-dihydroxy-2-naphthoic acid } \\ \text { DMH } & \text { 1,2-dimethylhydrazine } \\ \text { DSS } & \text { Dextran sodium sulphate } \\ \text { EFSA } & \text { European food safety authority } \\ \text { GRAS } & \text { Generally recognised as safe } \\ \text { IBD } & \text { Inflammatory bowel diseases } \\ \text { IBS } & \text { Irritable bowel syndrome } \\ \text { NSAID } & \text { Nonsteroidal anti-inflammatory drug } \\ \text { QPS } & \text { Qualified presumption of safety } \\ \text { SCFA } & \text { Short-chain fatty acid } \\ \text { TNBS } & \text { Trinitrobenzene sulphonic acid }\end{array}$

\section{Introduction}

Propionibacteria were first described at the end of the 19th century by E. von Freudenreich and S. Orla-Jensen, studying propionic acid fermentation in Emmental 
cheese, leading to propose the genus Propionibacterium (Orla-Jensen 1909). Propionibacteria are firmicutes with a high $\mathrm{G}+\mathrm{C}$ content, characterised as gram-positive, nonsporing, non-motile pleomorphic rods. They are anaerobic to aerotolerant and generally catalase positive. They grow optimally at $30{ }^{\circ} \mathrm{C}$ and are of neutral $\mathrm{pH}$. Cells are heterofermentative and metabolise a variety of substrates such as carbohydrates (including glucose, galactose, fructose and lactose), alcohols (glycerol and erythritol) and organic acids (lactate and pyruvate). Propionibacteria present a particular central carbon metabolic pathway, propionic fermentation. This fermentation involves the WoodWerkmann cycle (Wood et al. 1981) which produces propionate, acetate, succinate and carbon dioxide. The genus Propionibacterium is divided in two groups (Table 1) based on habitat of origin: classical or dairy propionibacteria (mainly isolated from dairy products such as cheese) and cutaneous propionibacteria (typically found on skin). Recently, a new species, Propionibacterium acidifaciens, was isolated from human carious dentine (Downes and Wade 2009). It was proposed as a member of the cutaneous group because it is closely related to Propionibacterium australiense. Dairy propionibacteria are commonly used as starter cultures in the dairy industry. Their main application is the ripening of Swiss-type cheeses, characterised by round "eyes". In these cheeses, they play an important role in characteristic flavour and opening. Opening is due to the production of carbon dioxide. Flavour is linked to the production by dairy propionibacteria of volatiles, mainly propionate and acetate, and other compounds derived from amino acid and lipid catabolisms (Dherbecourt et al. 2008, 2010; Langsrud and Reinbold 1973; Thierry et al. 2002, 2004a, b).

Some strains of dairy propionibacteria are also used in probiotic preparations, alone or in combination with lactic acid bacteria and/or bifidobacteria. A probiotic is defined as "a live microorganism which, when administered in adequate amounts, confers a health benefit on the host" (FAO et al. 2006). An increasing number of reports on potential probiotic properties of propionibacteria have been published. However, there is far less literature on the probiotic properties of propionibacteria than on the lactobacilli and bifidobacteria. Two book chapters (Jan et al. 2007; Ouwehand et al. 2004) and two earlier reviews (Mantere-Alhonen 1995; Vorobjeva et al. 1995) have reported on these potentialities. Recent evidence has been described in the literature but never reviewed. Moreover, no one has clearly sorted the probiotic characteristics

Table 1 Dairy and cutaneous Propionibacterium species

Dairy (classical) propionibacteria

P. acidipropionici

P. cyclohexanicum

P. freudenreichii subsp. freudenreichii

P. freudenreichii subsp. shermanii

P. jensenii

P. microaerophilum

P. thoenii
Cutaneous propionibacteria
$P$. acidifaciens
P. acnes
P. australiense
P. avidum
P. granulosum
P. propionicum

The species formerly known as P. inoccuum and P. lymphophilum have been reclassified as Propioniferax innocua (Yokota et al. 1994) and Propionimicrobium lymphophilum (Stackebrandt et al. 2002), respectively. 
described according to the level of evidence in the reports (in vitro, ex vivo, in vivo in animal models and in human beings). In addition, clinical studies have mainly reported on the use of dairy propionibacteria in complex bacterial mixtures and rarely with propionibacteria alone. This review provides an update on the probiotic potentialities of dairy propionibacteria and organises the potential health benefits according to the scientific level of the evidence. The paper only covers dairy propionibacteria, and only their probiotic potentialities in the gut. Uses as food preservatives and animal probiotics are not described here but have been extensively discussed in reports mentioned above. This paper includes six sections reviewing first selection criteria for using propionibacteria as probiotics, then probiotic potentialities of dairy propionibacteria that are suggested distinctly in vitro, ex vivo, in vivo in animal models and in human clinical study. In each section, we will successively evoke the impact of dairy propionibacteria on the gut microbiota (lowering pathogenic microorganisms and favouring beneficial ones), on different aspects of gut mucosa physiology and on the immune system. Finally, the production of others compounds related to propionibacteria and future trends in their further applications are discussed.

\section{Selection criteria for using propionibacteria as probiotics}

Selection of bacteria for probiotic application relies on criteria such as safety, technological and digestive stress survival, intestinal cell adhesion and human origin. The two last conditions are controversial and it is now recognised that they are not mandatory, although in some cases they may improve probiotic potential (Sanders 2008). These selection criteria are summarised in Table 2.

The safety of dairy propionibacteria is evidenced by the widespread consumption of Swiss-type cheese. The highest rate of Emmental consumption is found in France, where per capita consumption averages $4 \mathrm{~kg} \cdot \mathrm{year}^{-1}$. Propionibacteria are present in Emmental in concentrations close to $10^{9}$ bacteria per gram, and species Propionibacterium freudenreichii received the "Generally Recognised As Safe" (GRAS) (Mogensen et al. 2002). This opens the way to other applications such as probiotics, as discussed below. For example, one criterion studied for probiotic use is the absence of antibiotic resistance, because of the risk that any resistance will spread to intestinal microbiota. Dairy propionibacteria have natural resistance to few antibiotics and this resistance does not appear to be encoded by plasmids or other mobile genetic elements (Meile et al. 2008). In addition, dairy propionibacteria do not possess any known virulence factors, although some Propionibacterium thoenii and Propionibacterium jensenii strains have $\beta$-haemolytic activity (Meile et al. 2008). The European food safety authority has granted "Qualified presumption of safety" (QPS) status to species P. freudenreichii (Anonymous et al. 2008). No cytotoxic effect in mouse colonocytes (Zarate 2009) and no effect on the general health of rats (Huang et al. 2003; Lan et al. 2007a, 2008) or infants (Kukkonen et al. 2008) have been observed with strains of dairy propionibacteria. No indication of side effects from consuming dairy propionibacteria has been reported in any of the human trials reviewed here (Bouglé et al. 1999; El-Nezami et al. 2000b, 2006; Hatakka et al. 2007, 2008; Hervé et al. 2007; Hojo et al. 2002; Jan et al. 2002b; 
Kajander et al. 2005, 2007, 2008; Kajander and Korpela 2006; Kaneko 1999; Kekkonen et al. 2008b; Kuitunen et al. 2009; Kukkonen et al. 2007, 2008; Mitsuyama et al. 2007; Myllyluoma et al. 2005, 2007a, b; Ouwehand et al. 2004; Roland et al. 1998; Sarkar and Misra 1998, 2002; Satomi et al. 1999; Seki et al. 2004; Sidorchuk and Bondarenko 1984; Suzuki et al. 2006; Viljanen et al. 2005a, b).

In addition to their tolerance to technological stresses (cheese making, encapsulation, freeze-drying etc.), dairy propionibacteria present good constitutive survival under digestive stress. In vitro, many studies have described their natural ability to survive low $\mathrm{pH}$ conditions and exposure to bile (Huang and Adams 2004; Jan et al. 2002b; Leverrier et al. 2005; Mantere-Alhonen 1983; Suomalainen et al. 2008; Warminska-Radyko et al. 2002; Zarate et al. 2000). This tolerance is reinforced by a brief exposure to the same stress at a non-lethal level (Jan et al. 2000, 2001; Leverrier et al. 2003, 2004). Propionibacteria adapted in this way are able to survive $\mathrm{pH}$ values as low as two and bile salts' concentrations higher than those reported in the human gut. The probiotic vector is also important for digestive stress tolerance. Propionibacteria in cheese had better tolerance to acid challenge than free cultures (Jan et al. 2000). A yoghurt-type fermented milk provided P. freudenreichii with a high tolerance towards acid challenge, bile salts challenge and a succession of the two (Leverrier et al. 2005). Survival during gastrointestinal transit has also been reported in vivo in rodents (Huang et al. 2003; Lan et al. 2007a; Perez-Chaia and Zarate 2005) and human beings (Bouglé et al. 1999; Jan et al. 2002b; Suomalainen et al. 2008). A very high level of propionibacteria was detected in faeces but this concentration returned to the initial level a few days (orweeks) after consumption ceased.

Although controversial, another reported criterion for selecting probiotics is the ability to adhere to intestinal cells and/or mucosa. Dairy propionibacteria are able to adhere to immobilised mucus (Ouwehand et al. 2000; Thiel et al. 2004; Tuomola et al. 1999) and this adhesion was increased by the presence of other probiotic bacteria (Collado et al. 2007a; Ouwehand et al. 2002b). The authors suggest that adhesion to mucus is the result of non-specific interactions, because adhesion to mucus and to bovine serum albumin was similar. Dairy propionibacteria also adhere in vitro to human intestinal epithelial cell lines (Huang and Adams 2003; Lehto and Salminen 1997; Moussavi and Adams 2010). Zarate et al. (2002b) demonstrated the adhesion of propionibacteria ex vivo to isolated mouse intestinal epithelial cells and in vivo by a plate count of the viable propionibacteria adhering to intestinal cells.

These properties of dairy propionibacteria-safety, gastrointestinal transit survival and adherence to intestinal cells and mucosa-offer good prospects for their use as human probiotics. Table 3 summarises promising properties further described below.

\section{Probiotic potentialities of dairy propionibacteria suggested in vitro}

As regards modulation of gut microbiota, some authors have described a reduction in pathogen adhesion to immobilised mucus in the presence of $P$. freudenreichii subsp. shermanii JS, alone or in combination with other probiotic bacteria (Collado et al. 2006, 2007b, c, 2008; Myllyluoma et al. 2008). Collado et al. (2008) showed that $P$. freudenreichii subsp. shermanii JS is able to aggregate with pathogenic bacteria. 
Table 2 Selection criteria for using dairy propionibacteria as probiotics

\begin{tabular}{|c|c|c|c|c|}
\hline Characteristic/effect & Described in vitro & Described ex vivo & Described in animals & Described in humans \\
\hline Safety & N.D. & $\begin{array}{l}\text { No decrease in viability of } \\
\text { mouse colonocytes with } \\
\text { P. freudenreichii and } \\
\text { P. acidipropionici } \\
\text { (Zarate 2009). }\end{array}$ & $\begin{array}{l}\text { No effect on the general health } \\
\text { of rats (Huang et al. 2003; Lan } \\
\text { et al. 2007a, 2008). }\end{array}$ & $\begin{array}{l}\text { GRAS and QPS status (Meile et al. 2008; } \\
\text { Mogensen et al. 2002). Emmental } \\
\text { consumption. No effect on the general } \\
\text { health in human beings (Kukkonen et al. } \\
\text { 2008; Suzuki et al. 2006). }\end{array}$ \\
\hline $\begin{array}{l}\text { Digestive stress } \\
\text { tolerance and } \\
\text { survival in the gut }\end{array}$ & $\begin{array}{l}\text { Constitutive acid and bile tolerance } \\
\text { (Huang and Adams 2004; Jan et al. } \\
\text { 2002b; Leverrier et al. 2005; Mantere- } \\
\text { Alhonen 1983; Suomalainen et al. 2008; } \\
\text { Warminska-Radyko et al. 2002; Zarate } \\
\text { et al. 2000). Efficient adaptive response } \\
\text { to acid (Jan et al. 2000, 2001) and bile } \\
\text { (Leverrier et al. 2003) in } \\
\text { P. freudenreichii. }\end{array}$ & N.D. & $\begin{array}{l}\text { High propionibacteria survival in } \\
\text { rats (Huang et al. 2003; Lan et al. } \\
2007 \mathrm{a} \text { ) and mice (Perez-Chaia and } \\
\text { Zarate } 2005 \text { ). } 1-5 \mathrm{E}+10 \mathrm{cfu} \cdot \mathrm{day}^{-1 \mathrm{a}} \\
\text { (Huang et al. 2003). } 2 \mathrm{E}+0 \mathrm{cfu} \cdot \text { day }^{-1 \mathrm{a}} \\
\text { (Lan et al. 2007a). } 1 \mathrm{E}+09 \mathrm{cfu} \cdot \text { day }^{-1 \mathrm{a}, \mathrm{b}} \\
\text { (Perez-Chaia and Zarate } 2005 \text { ). }\end{array}$ & 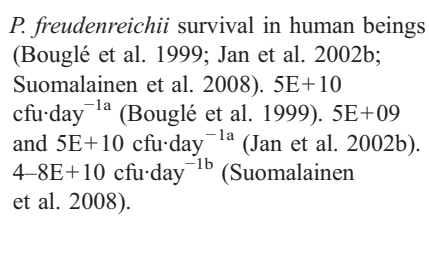 \\
\hline Gut adhesion & $\begin{array}{l}\text { Adhesion of } P \text {. freudenreichii to immobilised } \\
\text { mucus (Ouwehand et al. 2000; Thiel et al. } \\
\text { 2004; Tuomola et al. 1999). Adhesion of } \\
\text { propionibacteria to cultured human } \\
\text { intestinal cells (Huang and Adams } 2003 \text {; } \\
\text { Lehto and Salminen 1997; Moussavi and } \\
\text { Adams 2010). Increased adhesion of } \\
\text { P. freudenreichii to immobilised mucus } \\
\text { by probiotics combination (Collado et al. } \\
\text { 2007a; Ouwehand et al. 2002b). }\end{array}$ & $\begin{array}{l}\text { Adhesion of propionibacteria to } \\
\text { isolated mice intestinal cells } \\
\text { (Zarate et al. 2002b). }\end{array}$ & $\begin{array}{l}\text { Adhesion of propionibacteria }{ }^{a} \text { to mice } \\
\text { ileal epithelium (Zarate et al. 2002b). } \\
\text { Water with } 1 \mathrm{E}+09 \mathrm{cfu} \cdot \mathrm{mL}^{-1} \text {. }\end{array}$ & N.D. \\
\hline
\end{tabular}

N.D.: not determined.

${ }^{\text {a }}$ Propionibacteria alone.

${ }^{\mathrm{b}}$ Propionibacteria in combination with other probiotic bacteria.

Ingested quantities of propionibacteria are given when available. 
Table 3 Useful characteristics for probiotic applications and beneficial effects reported for dairy propionibacteria

\begin{tabular}{|c|c|c|c|c|}
\hline Characteristic/effect & Described in vitro & Described ex vivo & Described in animals & Described in humans \\
\hline \multirow[t]{6}{*}{ Gut microbiota } & $\begin{array}{l}\text { 1) Identification of bifidogenic } \\
\text { compounds (DHNA and ACNQ) in } \\
\text { P. freudenreichii (Isawa et al. 2002; } \\
\text { Kaneko 1999; Kaneko et al. 1994; } \\
\text { Kouya et al. 2007; Mori et al. 1997; } \\
\text { Roland et al. 1998; Warminska- } \\
\text { Radyko et al. 2002). }\end{array}$ & N.D. & $\begin{array}{l}\text { 1) Modulation of mice microbiota } \\
\text { by } P \text {. acidipropionici }{ }^{\text {a }} \text { (Perez- } \\
\text { Chaia et al. } 1999) \text {. Water with } \\
1 \mathrm{E}+08 \mathrm{cfu} \cdot \mathrm{mL}^{-1} \text {. }\end{array}$ & $\begin{array}{l}\text { 1) Enhancement of bifidobacteria by } P \text {. } \\
\text { freudenreichii }{ }^{\text {a }} \text { (Bouglé et al. 1999; Hojo et } \\
\text { al. 2002; Kaneko 1999; Roland et al. 1998; } \\
\text { Satomi et al. 1999). 5E }+10 \mathrm{cfu}^{-1} \text { day }^{-1} \\
\text { (Bouglé et al. 1999; Roland et al. 1998). }\end{array}$ \\
\hline & $\begin{array}{l}\text { 2) Coaggregation with pathogen } \\
\text { strains by } P \text {. freudenreichii (Collado } \\
\text { et al. 2008). }\end{array}$ & & $\begin{array}{l}\text { 2) Reduction in the level of } \\
\text { coliforms and increase in the } \\
\text { level of bifidobacteria and } \\
\text { lactobacilli in rat faecal } \\
\text { microbiota by P. freudenreichii }{ }^{\text {b }} \\
\text { (Sarkar and Misra 1998; 2002). }\end{array}$ & $\begin{array}{l}\text { 2) Modulation of intestinal microbiota in } \\
\text { children by P. freudenreichiib (Sarkar and } \\
\text { Misra 1998, 2002; Sidorchuk and } \\
\text { Bondarenko 1984). 1E }+10 \mathrm{cfu}^{-} \text {day }^{-1} \\
\text { (Sarkar and Misra 1998). }\end{array}$ \\
\hline & $\begin{array}{l}\text { 3) Reduction in pathogens adhesion to } \\
\text { immobilised mucus by } P \text {. } \\
\text { freudenreichii (Collado et al. 2006; } \\
\text { Collado et al. 2007b, c; } \\
\text { Vesterlund et al. 2006). }\end{array}$ & & $\begin{array}{l}\text { 3) Decrease in tissue colonisation } \\
\text { and increase in time survival to } \\
\text { S. typhimurium in mice by } P \text {. } \\
\text { acidipropionici }^{\text {a }}(\text { Alvarez et al. } \\
\text { 1996). } 1.2 \mathrm{E}+09 \mathrm{cfu}^{-1} \text { day }^{-1} \text {. }\end{array}$ & $\begin{array}{l}\text { 3) Increase in bifidobacteria and decrease in } \\
\text { bacteroides in human beings receiving } \\
\text { DHNA (Mitsuyama et al. 2007; Seki et al. } \\
\text { 2004). }\end{array}$ \\
\hline & $\begin{array}{l}\text { 4) Reduction in H. pylori adhesion on } \\
\text { intestinal cells by P. freudenreichii } \\
\text { (Myllyluoma et al. 2008). }\end{array}$ & & $\begin{array}{l}\text { 4) Increase in bifidobacteria in } \\
\text { mice receiving DHNA (Okada } \\
\text { et al. 2006a). }\end{array}$ & $\begin{array}{l}\text { 4) Improvement of the tolerance to the } \\
\text { treatment of } H \text {. pylori infection by } P \text {. } \\
\text { freudenreichii }{ }^{\text {b }} \text { (Myllyluoma et al. } 2005 \text {, } \\
\text { 2007a). 5-9E }+10 \text { cfu-day }{ }^{-1} \text { (Myllyluoma et } \\
\text { al. 2005). }\end{array}$ \\
\hline & $\begin{array}{l}\text { 5) Inhibition of } H \text {. pylori-induced cell } \\
\text { membrane leakage in Caco-2 cells } \\
\text { by } P \text {. freudenreichii (Myllyluoma et } \\
\text { al. 2008). }\end{array}$ & & $\begin{array}{l}\text { 5) DHNA recovery of loss of } \\
\text { Lactobacillus and } \\
\text { Enterobacteriaceae by DSS- } \\
\text { induced colitis in mice (Okada }\end{array}$ & $\begin{array}{l}\text { 5) Beneficial effect on gastric mucosa in } H \text {. } \\
\text { pylori infected patients by P. freudenreichii } \\
\text { (Myllyluoma et al. 2007b). } 2.5 \mathrm{E}+ \\
09 \mathrm{cfu}^{\mathrm{b}} \text { day }^{-1} \text {. }\end{array}$ \\
\hline & & & et al. 2006b). & $\begin{array}{l}\text { 6) Decreased prevalence in oral Candida in } \\
\text { elderly by P. freudenreichii }{ }^{\mathrm{b}} \text { (Hatakka et al. } \\
\text { 2007). } 5 \mathrm{E}+08 \text { cfu }^{-1 y^{-1}}{ }^{\text {. }}\end{array}$ \\
\hline $\begin{array}{l}\text { Beneficial metabolic } \\
\text { activities in the gut }\end{array}$ & $\begin{array}{l}\beta \text {-galactosidase activity enhanced in } \\
\text { the presence of bile by } P \text {. }\end{array}$ & N.D. & $\begin{array}{l}\text { 1) Increase in } \beta \text {-galactosidase } \\
\text { activity and propionic acid in }\end{array}$ & $\begin{array}{l}\text { 1) Modulation of SCFA in human faeces by } P \\
\text { freudenreichii }{ }^{\mathrm{a}} \text { (Jan et al. 2002b). } 5 \mathrm{E}+09\end{array}$ \\
\hline
\end{tabular}


Characteristic/effect

Described in vitro

Described ex vivo

Described in animals

Described in humans

acidipropionici (Zarate et al. 2000, 2002a).

Modulation of intestinal motility and absorption

Potential modulation of risk factors for

cancer

development
Cholesterol uptake by $P$.

freudenreichii (Somkuti and Johnson 1990).

1) Binding of carcinogenic toxins (ElNezami et al. 1998, 2002; Gratz et al. 2004, 2005; Halttunen et al. 2008; Haskard et al. 2001; Lee et al. 2003; Niderkorn et al. 2006; Zarate 2009).

2) Binding of heavy metals (Halttunen et al. 2008; Ibrahim et al. 2006)

3) Antimutagenic properties (Vorobjeva et al. 1995, 2001, 2004, 2008)

4) Induction of apoptosis (Jan et al. 2002a; Lan et al. 2007b)

5) Induction of NKG2D ligand
Binding of carcinogenic toxins (El-Nezami et al. 2000a; Gratz

et al. 2003, 2005; Zarate 2009).

nhanced iron absorption from the rat colon in the presence of $P$. freudenreichii (Bouglé et al.

1) Decrease in $\beta$-glucuronidase activity in mice caecum ${ }^{\text {a }}$ (PerezChaia et al. 1999). Water with $1 \mathrm{E}+08 \mathrm{cfu} \cdot \mathrm{mL}^{-1}$.

2) Increase in apoptosis in rats treated with DMH by $P$. freudenreichii ${ }^{\mathrm{a}}$ (Lan et al. 2008). $2 \mathrm{E}+10 \mathrm{cfu} \cdot \mathrm{day}^{-1}$. and $5 \mathrm{E}+10 \mathrm{cfu} \cdot \mathrm{day}^{-1}$

pionic a $($ Perez-Chat acidip Zarate 2005). $1 \mathrm{E}+09 \mathrm{cfu} \cdot \mathrm{day}^{-1}$

2) Propionic acid fermentation of P. freudenreichii ${ }^{\mathrm{a}}$ in rats (Lan et P. acidipropionici $i^{\mathrm{a}}$ (PerezChaia et al. 1995). Water with $1 \mathrm{E}+08 \mathrm{cfu} \cdot \mathrm{mL}^{-1}$ $1 \mathrm{E}+11 \mathrm{cfu} \cdot \mathrm{day}^{-1}$.
) Propionic acid fermentation of $P$ freudenreichii in human ${ }^{\mathrm{a}}$ (Hervé et al. 2007).

1) Constipation alleviation by $P$. freudenreichii ${ }^{\mathrm{a}}$ (Hojo et al. 2002).

2) Modulation of digestive motility by propionibacteria $^{\mathrm{a}}$ (Bouglé et al. 1999). $5 \mathrm{E}+$ $10 \mathrm{cfu} \cdot \mathrm{day}^{-1}$.

3) Increase in defecation frequency in elderly by P. freudenreichii ${ }^{\mathrm{a}, \mathrm{b}}$ (Ouwehand et al 2002a; Seki et al. 2004).

1) Reduction in the faecal level of azoreductase activity in elderly subjects by $P$. freudenreichii ${ }^{\mathrm{b}}$ (Ouwehand et al. 2002a).

2) Decrease in $\beta$-glucosidase and urease by $P$. freudenreichii $^{\mathrm{b}}$ (Hatakka et al. 2008). 2E+ $10 \mathrm{cfu} \cdot \mathrm{day}^{-1}$.

$3)$ Decrease in $\beta$-glucuronidase activity by $P$. freudenreichii ${ }^{\mathrm{b}}$ (Kajander et al. 2007). 2E+ $09 \mathrm{cfu}^{\mathrm{day}}{ }^{-1}$.

4) Reduction in the faecal level of aflatoxin $B$ by $P$. freudenreichii ${ }^{\mathrm{b}}$ (El-Nezami et al. 2000b).

5) Reduction of colon exposure to aflatoxin $\mathrm{B}$ 
expression on cancer cells by $P$. freudenreichii and P. acidipropionici (Andresen et al. 2009)

Healing on intestina inflammation
N.D.
Immunomodulation

1) Inhibition of $H$. pylori-induced IL8 and $\mathrm{PGE}_{2}$ released in Caco-2 cells by $P$. freudenreichii (Myllyluoma et al. 2008).

2) Induction of NKG2D ligand expression on human-activated $\mathrm{T}$ lymphocytes by $P$. freudenreichii and $P$. acidipropionici (Andresen et al. 2009)

3) Induction of TNF- $\alpha$ and IL-10 in PBMC by P. freudenreichii (Kekkonen et al. 2008a).
1) Healing by $P$. freudenreichit and $P$. acidipropionici $i^{\mathrm{a}}$ of

TNBSinduced colitis in rats

(Michel et al. 2005; Uchida and Mogami 2005).

2) Attenuation of DSS-induce colitis in mice by DHNA (Okada et al. 2006b)

1) Stimulation of mice phagocytosis by $P$. acidipropionici $^{\text {a }}$ (Morata de Ambrosini et al. 1998; PerezChaia et al. 1995). Water with $1 \mathrm{E}+08 \mathrm{cfu} \cdot \mathrm{mL}^{-1}$ (Perez-Chaia et al. 1995).

2) Stimulation of lymphocyte proliferation in mice by $P$. freudenreichii and $P$. jensenii (Adams et al. 2005; Kirjavainen et al. 1999). $1 \mathrm{E}+08 \mathrm{cfu} \cdot \mathrm{day}^{-1}$ (Adams et al. 2005). 1E+09 and $1 \mathrm{E}+12 \mathrm{cfu} \cdot \mathrm{kg}^{-1}$ body weight $\cdot$ day $^{-1}$ (Kirjavainen et al. 1999).

3) Increase in the level of secreted IgA by $P$. acidipropionici in mice $^{\text {a }}$ (Alvarez et al. 1996). $\mathrm{x} 1.2 \mathrm{E}+09 \mathrm{cfu} \cdot \mathrm{day}^{-1}$.

4) Anti-inflammatory effect of DHNA (Okada et al. 2006a) by $P$. freudenreichii ${ }^{\mathrm{b}}$ (El-Nezami et al. 2006). $2-5 \mathrm{E}+10 \mathrm{cfu} \cdot \mathrm{day}^{-1}$

1) Improvement of the clinical activity index scores in active ulcerative colitis patients receiving DHNA (Mitsuyama et al. 2007; Suzuki et al. 2006)

2) Alleviation of the symptoms of irritable bowel syndrome by $P$. freudenreichii ${ }^{\mathrm{b}}$ (Kajander et al. 2005, 2008; Kajander and Korpela 2006). 1-2E $+09 \mathrm{cfu} \cdot \mathrm{day}^{-1}$.

1) Decrease in serum levels of CRP by $P$. freudenreichii ${ }^{\mathrm{a}}$ (Kekkonen et al. 2008b). $3.3 \mathrm{E}+10 \mathrm{cfu} \cdot \mathrm{day}^{-1}$.

2) Induction of IL-4 secretion in infants PBMC with CMA by $P$ freudenreichii (Pohjavuori et al. 2004). $2 \mathrm{E}+09 \mathrm{cfu} \cdot \mathrm{day}^{-1}$

3) Prevention of IgE-associated allergy in caesarean-delivered children by $P$. freudenreichii ${ }^{\text {b }}$ (Kuitunen et al. 2009). 2E+ $09 \mathrm{cfu} \cdot \mathrm{day}^{-1}$.

4) Increase in the resistance to respiratory infections during the first 2 years of life by $P$. freudenreichii $^{\mathrm{b}}$ (Kukkonen et al. 2008). 2E+ $09 \mathrm{cfu}^{\mathrm{day}}{ }^{-1}$.

5) Prevention of atopic eczema/dermatis 
N.D.: not determined.

${ }^{a}$ Propionibacteria alone.

${ }^{\mathrm{b}}$ Propionibacteria in combination with other probiotic bacteria.

Ingested quantities of propionibacteria are given when available. 
Myllyluoma et al. (2008) described inhibition of Helicobacter pylori adhesion to a human intestinal epithelial cell line by P. freudenreichii subsp. shermanii JS alone. The authors observed the same inhibition with a combination with other probiotic bacteria. This combination also inhibited $H$. pylori-induced cell membrane leakage (Myllyluoma et al. 2008). A major advantage of dairy propionibacteria for microbiota modulation is their ability to enhance the growth of bifidobacteria (Kaneko et al. 1994; Moussavi and Adams 2010; Roland et al. 1998; WarminskaRadyko et al. 2002). Two bifidogenic compounds have been already identified in vitro: 1,4-dihydroxy-2-naphthoic acid (DHNA) (Isawa et al. 2002) and 2-amino-3carboxy-1, 4-naphthoquinone (ACNQ) (Kaneko 1999; Mori et al. 1997). DHNA is a precursor of menaquinone (vitamin K2) biosynthesis in bacteria. Some DHNA is released from propionibacteria during growth (Furuichi et al. 2006). ACNQ stimulated the growth of bifidobacteria at an extremely low concentration $(0.5 \mathrm{nM})$ and enhanced the activity of NADH peroxidase and NADH oxidase in bifidobacteria. ACNQ, which may derive from DHNA, is an electron acceptor of NAD(P)H diaphorase and an electron donor of $\mathrm{NAD}(\mathrm{P}) \mathrm{H}$ peroxidase in bifidobacteria (Kaneko 1999; Mitsuyama et al. 2007; Yamazaki et al. 1998, 1999). NAD(P)+regeneration is thought to be responsible for the ability of propionibacteria to stimulate bifidobacteria growth via DHNA and ACNQ. It is also worth noting that propionate, the main end-product of propionibacteria fermentation, is considered to favour the growth of bifidobacteria (Kaneko et al. 1994); a property used in bifidobacteria selective culture media (Hartemink and Rombouts 1999).

As regards modulation of gut enzyme activity, some bacterial species including yoghurt starters are efficient in treating lactose intolerance by enhancing $\beta$ galactosidase activity in the intestine (de Vrese et al. 2001). Propionibacterium acidipropionici and $P$. freudenreichii have a high level of $\beta$-galactosidase activity at $37^{\circ} \mathrm{C}$ (Zarate et al. 2002a) which was even improved in the presence of bile (Zarate et al. 2000, 2002a), by permeabilisation of cells. The authors conclude that the environment in the human intestine may be adequate for $\beta$-galactosidase synthesis and activity. They also suggested that a fermented dairy product constitutes a good vector for high $\beta$-galactosidase activity. Moreover, the enzyme withstood the cooking temperature of Swiss-type cheeses and proved to be stable during storage at low temperatures.

Propionate was recently shown to enhance expression of epithelial calcium channel $\mathrm{ECaC}_{2}$, which is involved in the transcellular route of intestinal calcium absorption in Caco-2 cells (Fukushima et al. 2009). This would at least partly explain why propionate was shown to enhance calcium absorption from the human colon (Trinidad et al. 1999). Intestinal absorption of lipids may be modulated by the consumption of probiotics, including dairy propionibacteria. Somkuti and Johnson found evidence of adsorption of cholesterol to $P$. freudenreichii cells. This adsorption was mainly passive, as $70 \%$ of the cholesterol removed from the medium could be recovered by solvent extraction fromwashed cells (Somkuti and Johnson 1990). This suggests, however, that the presence of dairy propionibacteria in the gut may reduce the bioavailability of cholesterol.

Propionibacteria may contribute to reduction of risk factors for cancer development particularly through the ability to bind, in vitro, carcinogenic compounds like mycotoxins (El-Nezami et al. 2002; Niderkorn et al. 2006) and 
especially aflatoxin $B_{1}$ (El-Nezami et al. 2000a; Gratz et al. 2004, 2005; Halttunen et al. 2008; Haskard et al. 2001; Lee et al. 2003), cyanotoxins such as microcystin-LR (Halttunen et al. 2008), plant lectins such as concanavilin A and jacalin (Zarate 2009), and also some heavy metals such as cadmium and lead (Halttunen et al. 2008; Ibrahim et al. 2006). The organic toxins cited above are particularly associated with colorectal cancer.Heavymetals havemany deleterious effects on human health including kidney or other cancers. These data suggest thatdairypropionibacteriamayhelp to reduce gut absorption of carcinogenic compounds and so limit the emergence or development of cancer. In addition, these bacteria may be used as detoxifying additives in food contaminated by high levels of this kind of carcinogenic compound which are very difficult to remove. Vorobjeva et al. $(1995,2001,2008)$ demonstrated the antimutagenic properties of dairy propionibacteria.

P. freudenreichii subsp. shermanii prevented mutations caused by various mutagenic agents. The suggested active component is a cysteine synthase of $35 \mathrm{~kg} \cdot \mathrm{mol}^{-1}$, secreted into the extracellular environment (Vorobjeva et al. 2008). Another potential anti-cancer property is the ability of $P$. freudenreichii and $P$. acidipropionici to induce apoptosis of colorectal carcinoma cells owing to the action of shortchain fatty acids, especially propionate, on cancer cell mitochondria (Jan et al. 2002a, Lan et al. 2007b). These data suggest that the use of dairy propionibacteria could reduce the incidence of colon cancer or help to treat this cancer, which is the second most fatal cancer in Europe. In addition, $P$. freudenreichii and $P$. acidipropionici induced NKG2D ligand expression on various cancer cells and the authors speculate that the pro-apoptotic effectmay also bemediated by this overexpression (Andresen et al. 2009).

$P$. freudenreichii has been observed to modulate the immune system in vitro by inhibition of $H$. pylori-induced IL-8 and $\mathrm{PGE}_{2}$ release in human intestinal epithelial cells (Myllyluoma et al. 2008). These anti-inflammatory effects did not persist when $P$. freudenreichii subsp. shermanii JS was used in combination with Lactobacillus rhamnosus GG, L. rhamnosus LC-705 and B. breve Bbi99. The authors stress the importance of characterising the individual strains to improve the therapeutic response of probiotics used in combination. In addition, $P$. freudenreichii and $P$. acidipropionici induced NKG2D ligand MICA/B expression on human-activated $\mathrm{T}$ lymphocytes without affecting this expression on resting peripheral blood cells. This effect was also observed with propionate alone and to a lesser extent by acetate (Andresen et al. 2009). Expression is stimulated by higher promoter activity due to a mechanism that depends on intracellular calcium. The authors suggest that preoperative treatment with cutaneous propionibacteria strains may produce beneficial immunostimulation and increased survival of patients with colorectal carcinoma. As regards cytokine production, $P$. freudenreichii subsp. shermanii JS was able to induce TNF- $\alpha$ and IL10 production in human PBMCs (Kekkonen et al. 2008a). The anti-inflammatory actions of IL-10 could be helpful in the treatment of inflammatory conditions or diseases. Interestingly, P. freudenreichii subsp. shermanii JS induced the expression of IL-12 (pro-inflammatory cytokine) only weakly (Kekkonen et al. 2008a), suggesting useful implication to treat colitis as reported earlier (Foligné et al. 2007). E. coli DH5 $\alpha$-induced IFN- $\gamma$ production was also reducedwhen it was combined with $P$. freudenreichii subsp. shermanii JS (Kekkonen et al. 2008a). 


\section{Probiotic potentialities of dairy propionibacteria studied ex vivo}

P. freudenreichii enhanced iron absorption from the rat proximal colon ex vivo, via the production of short-chain fatty acids (SCFA), especially propionate (Bouglé et al. 2002). The authors suggest that this absorption may be enhanced in vivo by local production of SCFA. This suggests a positive effect of dairy propionibacteria on the bioavailability of dietary iron for uptake by the liver and spleen.

The ability of dairy propionibacteria to bind carcinogenic compounds like aflatoxin $\mathrm{B}_{1}$ has also been described ex vivo (El-Nezami et al. 2000a; Gratz et al. 2003, 2005). A mixture of $P$. freudenreichii subsp. shermanii JS and L. rhamnosus LC- 705 was able to bind aflatoxin $B_{1}$ and tissue uptake of this carcinogen was reduced when probiotic bacteria were present in a duodenal loop. Consequently, this probiotic mixture could delay, but not prevent, aflatoxin $\mathrm{B}_{1}$ absorption in duodenal loops. Hence, ingestion of dairy propionibacteria may limit bioavailability, absorption and metabolisation of these carcinogenic compounds and so decrease cancer emergence risk.

\section{Probiotic potentialities of dairy propionibacteria in animal models}

Sarkar and Misra (1998, 2002) showed a decline in the total number of faecal bacteria in rats fed a fermented milk containing Bifidobacterium bifidum, $P$. freudenreichii subsp. shermanii and either L. acidophilus or not. Especially, the number of coliforms was decreased, but an increase in the bifidobacteria population was observed. Perez-Chaia et al. (1999) noticed a similar microbiota modulation in mice consuming $P$. acidipropionici, with fewer anaerobes and coliforms in the caecal content. Moreover, Alvarez et al. (1996) reported that feeding a P. acidipropionici CRL 1198 supplement to mice prior to Salmonella typhimurium administration afforded a partial protection against the pathogen colonisation. Indeed, a decrease in tissue colonisation by $S$. typhimurium and an increase in the mice survival rate were observed. The $P$. freudenreichii component DHNA ingested by mice presenting a dextran sodium sulphate (DSS)-induced colitis led to a modulation of the microbiota, including a weaker drop in the Lactobacillus and Enterobacteriaceae intestinal populations caused by DSS (Okada et al. 2006b). DHNA also increased intestinal bifidobacteria population in mice suffering from non-steroidal anti-inflammatory drug (NSAID)-induced colitis (Okada et al. 2006a). Bifidobacterium is probably the most amply documented genus of the human microbiota studied for probiotic properties. Thus, stimulation of bifidobacteria growth by dairy propionibacteria therefore constitutes a key probiotic potential.

Metabolic activity of $P$. freudenreichii has been described in the gastrointestinal tract of human microbiota-associated rats (Lan et al. 2007a). Transcriptional activity within the intestine was demonstrated by the presence of $P$. freudenreichii-specific transcarboxylase mRNA. Transcarboxylase is involved in propionic acid metabolism. Strain TL133 also increased the concentrations of acetate, propionate and butyrate in rat caecal contents (Lan et al. 2007a). In another study, mice fed $P$. acidipropionici CRL 1198 showed increased $\beta$-galactosidase activity and enhanced propionic acid levels in the caecum (Perez-Chaia and Zarate 2005). This strain also 
tends to reverse the hyperlipidemic effect of a high lipid diet (Perez-Chaia et al. 1995). This effect can be attributed to modulation of liver metabolism by absorbed propionic acid but can also be linked to the cholesterol-binding activity described above (Somkuti and Johnson 1990). Hypolipidemic effects of dairy propionibacteria should be confirmed in human studies.

Many bacterial enzymes, including $\beta$-glucosidase, $\beta$-glucuronidase, azoreductase and urease, are involved in producing carcinogens within the gut. Many probiotic studies have monitored the activity of these faecal enzymes. A potential modulation of risk factors for carcinogenesis has been observed in animal models. In mice fed $P$. acidipropionici, $\beta$-glucuronidase activity was lower than in controls on a conventional diet (Perez-Chaia et al. 1999). With a red cooked meat supplement, the $\beta$-glucuronidase activity increased in the control mice. In the faeces of propionibacteria-supplemented mice, $\beta$-glucuronidase activity increased much less than in the control at the beginning of the meat diet and decreased thereafter. Propionibacteria supplementation prevented the increase in $\beta$-glucuronidase activity with the red meat diet. The authors also describe a slight reduction in azoreductase and nitroreductase activity (Perez-Chaia et al. 1999). Lan et al. (2008) report that $P$. freudenreichii TL133 increased induction of apoptosis in colonic mucosal crypts of human microbiota-associated rats treated with the carcinogen 1,2-dimethylhydrazine $(\mathrm{DMH})$. The administration of propionibacteria alone did not increase the number of apoptotic cells in healthy colonic mucosa. This study demonstrates the ability of $P$. freudenreichii to favour apoptotic depletion of damaged cells at an early stage of malignant cell transformation in rats.

As regards intestinal inflammation, in some studies, colonic infusion with $P$. acidipropionici (Michel et al. 2005) or oral supplementation with a milk whey culture of $P$. freudenreichii ET-3 (Uchida and Mogami 2005) reduced the severity of TNBS-induced colitis in rats. The healing of TNBS-induced colitis was also observed with oral administration of propionate (Uchida and Mogami 2005). In therapeutic and preventive studies, DHNA improved the survival rate and histological damage scores of mice with DSS-induced colitis (2006b). DHNA attenuated colonic inflammation not only by balancing intestinal bacterial ecosystem but also by suppressing lymphocyte infiltration (Okada et al. 2006b). Okada et al. (2006a) report that DHNA had an anti-inflammatory effect on NSAID-induced colitis in IL-10-knockout mice through increased numbers of Bifidobacteria and suppression of inflammatory cell infiltration.

As regards immunomodulation, Perez-Chaia et al. (1995) observed an improvement in carbon clearance in mice fed with P. acidipropionici CRL 1198, indicating an enhanced phagocytic function of the reticuloendothelial system. Administration of this strain prior to $S$. typhimurium pathogen inoculation led to an increase in both anti-S. typhimurium IgA levels and numbers of cells producing the antibody (Alvarez et al. 1996). Moreover, P. acidipropionici enhanced the phagocytic activity of isolated mouse peritoneal macrophages (Perez-Chaia et al. 1995), which was higher with mice fed propionibacteria than in the controls. The orally administered $P$. acidipropionici showed this immunostimulating activitywith isolated cell wall but not with isolated peptidoglycan (Morata de Ambrosini et al. 1998). Immune system modulation by dairy propionibacteria may be related to the chemical composition of the cell walls, particular molecules protruding from the surface. Oral treatment of 
mice with $P$. freudenreichii subsp. shermanii JS in combination with L. rhamnosus GG increased T-cell and B-cell proliferation after stimulation with concanavalin A (T-cell mitogen), and lipopolysaccharide (B-cell mitogen), respectively (Kirjavainen et al. 1999). The authors suggest that these results may indicate that the splenic lymphocytes acquired a higher tolerance to the cytotoxic effects of the mitogens. They suggest that they are related to the capacity of dairy propionibacteria to bind this lectin in vitro, as cited above. Another study showed a higher T-cell proliferation of splenic lymphocytes with P. jensenii 702 inmice receiving soluble Mycobacterium tuberculosis antigens (Adams et al. 2005). The strain has been patented as an adjuvant for oral vaccines (Adams et al. 2003, 2008).

\section{Probiotic potentialities of dairy propionibacteria in human}

Many teams have studied the impact of dairy propionibacteria on the human microbiota. In several independent studies, ingestion of $P$. freudenreichii in the form of whey cultures, whether heat-inactivated (Kaneko 1999; Satomi et al. 1999) or not (Hojo et al. 2002), or as freeze-dried live bacteria forms (Bouglé et al. 1999; Roland et al. 1998), resulted in a higher faecal bifidobacteria population in human beings. Sarkar and Misra $(1998,2002)$ showed that a fermented milk containing $B$. bifidum, $P$. freudenreichii subsp. shermanii and either L. acidophilus or not led to a decline in coliforms and to an increase in bifidobacteria in the faeces of infants receiving the product. Whey cultures with $P$. freudenreichii ET-3 also triggered a decrease in Clostridium perfringens (Seki et al. 2004) and Bacteroides populations (Mitsuyama et al. 2007). In children suffering from intestinal dysbacteriosis, consumption of a milk containing $P$. freudenreichii subsp. shermanii and $L$. acidophilus restored of the microbiota, thus shortening the convalescence period during antibiotherapy (Sidorchuk and Bondarenko 1984). Hatakka et al. (2007) report that a cheese containing a mixture of probiotics ( $L$. rhamnosus GG, $L$. rhamnosus LC705 and P. freudenreichii ssp. shermanii JS) reduced the risk of high yeast counts, especially Candida sp., in the mouth of elderly people. These authors also observed that probiotic intervention reduced the risk of hyposalivation and a dry mouth sensation and can therefore be considered beneficial to oral heath in general. In fact, the authors suggest that the absence of protective probiotics and increased hyposalivation might explain the enhanced Candida growth in the control group. A probiotic supplementation with L. rhamnosus GG, L. rhamnosus LC70, B. breve Bb99 and P. freudenreichii ssp. shermanii JS did not significantly reduce the frequency of new or aggravated symptoms caused by antibiotic treatment during H. pylori eradication (Myllyluoma et al. 2005), although this probiotic combination has exhibited promising anti-Helicobacter properties in vitro (see section above). However, taking total symptom severity into account, this study suggests improved tolerance of the anti-H. pylori treatment. The authors also show that the probiotic bacteria survived in the gastrointestinal tract despite the intensive antimicrobial therapy (Myllyluoma et al. 2005). A more recent study has confirmed that the same probiotic mixture counteracts the effects of antibiotic treatment against $H$. pylori (Myllyluoma et al. 2007a). In particular, reduced $H$. pylori-induced inflammation of the gastric mucosa was observed (Myllyluoma et 
al. 2007b). Altogether, these results strongly suggest that the tested probiotics, containing $P$. freudenreichii subsp. shermanii JS, may be helpful during the treatment of $H$. pylori infection.

Hojo et al. (2002) report that a high faecal bifidobacteria level due to $P$. freudenreichii ET-3 supplementation was linked to an increased number of defecations in constipated female volunteers. Stool frequency was also significantly increased by administration of a $P$. freudenreichii culture in healthy human subjects (Kaneko 1999) and in elderly subjects (Seki et al. 2004). In another study, elderly subjects receiving a $L$. rhamnosus and $P$. freudenreichii-supplemented juice also exhibited an increase in defecation frequency (Ouwehand et al. 2002a). This probiotic property is interesting because constipation is a common problem in elderly subjects. Another clinical study reported a limited effect on segmental colonic motility, including slower transit in the left colon (Bouglé et al. 1999). The authors suggested that propionibacteria may regulate transit when this one is disturbed.

The consumption of a juice supplemented with L. rhamnosus LC-705 and $P$. freudenreichii subsp. shermanii JS led to decreased faecal azoreductase activity in elderly subjects (Ouwehand et al. 2002a). The same probiotic combination was used in healthy men and led to a non-significant decrease in $\beta$-glucosidase activity of $10 \%$ and in urease activity of $13 \%$ (Hatakka et al. 2008). In irritable bowel syndrome patients, a probiotic mixture containing $L$. rhamnosus GG, L. rhamnosus $\mathrm{LC}-705, B$. breve $\mathrm{Bb} 99$ and $P$. freudenreichii subsp. shermanii JS led to a decrease in $\beta$ glucuronidase activity in most people in the probiotic group (Kajander et al. 2007). A clinical trial investigated the effect of a probiotic preparation containing $L$. rhamnosus LC-705 and P. freudenreichii subsp. shermanii JS on levels of aflatoxin $\mathrm{B}_{1}$ in human faecal samples. Following probiotic administration, there was a significant reduction in the faecal level of aflatoxin $\mathrm{B}_{1}$ and this decrease continued during the follow-up period (El-Nezami et al. 2000b). Another study with the same probiotic supplementation in young men from Southern China found an increase in urinary samples with negative aflatoxin $\mathrm{B}_{1}-\mathrm{N}^{7}$-guanine and a decrease in the concentration of urinary aflatoxin $\mathrm{B}_{1}-\mathrm{N}^{7}$-guanine in the probiotic group (El-Nezami et al. 2006). Aflatoxin $B_{1}-N^{7}$-guanine is a marker for a biologically effective dose of aflatoxin. The probiotic supplementation thus reduced the organism's exposure to this carcinogen.

A commercial preparation of bifidogenic growth stimulator (BGS), which is produced by $P$. freudenreichii ET-3, led to an improvement in the clinical activity scores of ulcerative colitis patients (Mitsuyama et al. 2007; Suzuki et al. 2006). Patients also showed a decrease in the endoscopic index and an improvement in serum haemoglobin and albumin concentrations (Suzuki et al. 2006). An increase in all SCFA concentrations was measured after BGS ingestion but this was significant only for butyrate (Suzuki et al. 2006). The authors suggest that BGS restores a healthy microbial balance, thus favouring beneficial competitive interactions which may prevent or treat ulcerative colitis.

Kekkonen et al. (2008b) report that a probiotic intervention with $P$. freudenreichii subsp. shermanii JS in healthy adults led to a reduction in the serum level of Creactive protein (CRP) compared to a placebo control. CRP being a sensitive inflammation marker, this result confirms the anti-inflammatory potential of dairy 
propionibacteria. In a randomised, placebo-controlled, double-blind trial was performed in Helsinki on infants at high risk of allergy, a probiotic mixture containing L. rhamnosus GG, L. rhamnosus LC-705, B. breve $\mathrm{Bb} 99$ and $P$. freudenreichii subsp. shermanii JS was given daily for 6 months after birth and compared to a placebo (Kuitunen et al. 2009; Kukkonen et al. 2007, 2008). Two years after birth, less antibiotic prescription and fewer respiratory infections were reported in the supplemented infant group, whatever the mode of delivery (Kukkonen et al. 2008). In addition, less eczema and less atopic eczema were diagnosed in the treated group (Kukkonen et al. 2007). Five years following birth, significant differences were detected among caesarean-delivered children: less IgEassociated disease occurred, particularly eczema, and less IgE sensitisation was detected (Kuitunen et al. 2009). Thus, during the first stages of life, probiotic supplementation including propionibacteria seems to promote immune system maturation, preventing infections and allergies. In addition, such supplementation would further counteract disorders linked to caesarean delivery such as delayed colonisation of the gut by bifidobacteria and lactobacilli. Another randomised, placebo-controlled, double-blind trial tested the same probiotic mixture in infants with atopic eczema-dermatitis syndrome (AEDS) and suspected cow's milk allergy (CMA). Soluble E-selectin and plasma IL-10 levels were higher after probiotic supplementation than after placebo treatment (Viljanen et al. 2005b) and faecal IgA levels tended to be higher in the probiotic group (Viljanen et al. 2005a). Another study showed that a mixture of $P$. freudenreichii subsp. shermanii JS, L. rhamnosus GG and LC-705 and B. breve Bbi99 increased IL-4 secretion and tended to stimulate IFN- $\gamma$ secretion in PBMCs of infants with CMA (Pohjavuori et al. 2004). This may offer clinical benefits in the treatment of allergic diseases by immunologic means. Altogether, these clinical data indicate beneficial immunomodulation by a mixture of gram-positive bacteria including $P$. freudenreichii subsp. shermanii JS, with a reported anti-inflammatory effect of the latter. Further clinical data should pin down the role of dairy propionibacteria per se.

\section{Production of other compounds and future trends}

Many other properties of dairy propionibacteria can be regarded as beneficial (Hugenholtz et al. 2002). They secrete bacteriocins (Holo et al. 2002), anti-fungal compounds (Lind et al. 2007) and anti-viral compounds (Cutting et al. 1962; Furusawa et al. 1965, 1967; Ramanathan et al. 1965, 1966, 1968, 1973) and are therefore used as food preservatives. Propionate, being an SCFA, has been investigated for its health effects. In particular, preliminary in vitro investigations suggest that propionate has a role inducing apoptosis of gastric cancer cells (Matthews et al. 2007) and in preventing colon cancer cell colonisation (Emenaker and Basson 1998). In vivo, propionate increased secretion of intestinal mucus in rats (Shimotoyodome et al. 2000) and human colorectal calcium absorption (Trinidad et al. 1999). The suggested beneficial effects of propionate suggest similar properties for dairy propionibacteria, mediated by their metabolism end-products. As an example, induction of the satietogen peptide PYY by SCFAs having been reported (Cherbut et al. 1998), Ruijschop et al. (2008) tested a dairy product fermented by 
lactic acid bacteria and propionibacteria in a human study. After consumption of this product, subjects felt significantly fuller, were less hungry and had less desire to eat (Ruijschop et al. 2008). However, the authors report no effect on ad libitum food consumption. Also of health interest is the capacity of dairy propionibacteria to improve the nutritional quality of fermented products by synthesising vitamins, trehalose and conjugated linoleic acid (CLA). Dairy propionibacteria synthesise vitamin $\mathrm{B}_{8}$ (biotin), $\mathrm{B}_{9}$ (folic acid) and $\mathrm{B}_{12}$ (cobalamin) (Hugenholtz et al. 2002). Folic acid has been described as an agent for colorectal cancer prevention but this claim is controversial (Hubner and Houlston 2009). Trehalose has been observed to reduce the level of enterohaemorrhagic Escherichia coli O157:H7 in ruminants because this sugar can be used by commensal E. coli but not by the 0157:H7 strain (de Vaux et al. 2002). The broad spectrum of biological effects reported for conjugated linoleic acids (Churruca et al. 2009; Wahle et al. 2004) includes the anticarcinogenic properties of rumenic acid, the cis-9, trans-11 stereoisomer of CLA (Lavillonniere et al. 2003; Lock et al. 2004). P. freudenreichii has been shown to convert linoleic acid to rumenic acid (McIntosh et al. 2009; Rainio et al. 2001, 2002; Vahvaselka and Laakso 2010; Wang et al. 2007) and the corresponding mechanisms have been identified (McIntosh et al. 2009). As the authors of that study suggest, rumenic acid formation in the human gut could promote health.

The technological qualities of dairy propionibacteria constitute a key advantage for their uses as probiotics. They survive the technological stresses imposed during freeze-drying, spray-drying, reconstitution in milk, cheese making and storage at low temperatures. Dairy propionibacteria ferment a wide range of carbohydrate substrates. Such remarkable adaptability, robustness and versatility are consistent with the occurrence of propionibacteria in various niches and should allow their growth and/or viability in a variety of probiotic vectors.

Most of the clinical studies have been conducted using mixtures of bacteria from different genera. The development of a pure culture of dairy propionibacteria in a food grade vector will make it possible to pin down their specific probiotic potential in human beings. However, synergistic effect between different probiotics should also be investigated in the different fields of beneficial activity. In addition, complex interactions between ingested probiotics and the complex gut microbiota should be taken into consideration. In this context, the ability of dairy propionibacteria to modulate this microbiota, beyond the propionibacteria population itself, is of particular interest.

Probiotic properties "in general", including bifidobacteria and lactobacilli, differ from a species to another and are straindependent. It is therefore necessary to screen a large number of dairy propionibacteria in order to select strains with the best potentialities for dedicated applications. In this context, such approach to study immunomodulation of a large set of diverse single propionibacteria both in vitro (PBMC) and in vivo (experimental colitis and infectious mice models) have already been initiated and developed (Deutsch/ Foligné et al., personal communication) and should fill some gaps soon. Besides classical screening methods, the first dairy Propionibacterium genome from a $P$. freudenreichii subsp. shermanii strain is expected to be available soon. Genomic data will allow new mechanistic investigations of its probiotic potential (Klaenhammer et al. 2005). 


\section{Conclusion}

In conclusion, although more experimental data are available concerning probiotic applications of bifidobacteria and lactobacilli, dairy propionibacteria also deserve attention. Indeed, there is now specific promising evidence from dairy propionibacteria regarding beneficial modulation of colon microbiota and carcinogenesis together with anti-inflammatory and immune properties. Future works should focus on the development of molecular tools and appropriate delivery vectors as well as on selecting the best strains. Progress on these aspects will allow specific clinical studies. These in turn should lead to a better understanding and exploitation of the beneficial effects of dairy propionibacteria in the different compartments of the gastrointestinal tract.

Individual probiotics demonstrate unique, specific biological effects. Knowledge of the specific effects of each probiotic strain will allow the development of probiotic mixtures adapted to particular cases or pathologies. Selecting (mixtures of) probiotics for use in disease(s) treatment will be guided by improved knowledge on action mechanisms based on established experimental models from in vitro to clinic. Knowledge of probiotic mechanisms may allow us to select the strain(s) with the best possible expected biological outcome.

However, bench-to-bedside clinical trials will remain necessary to validate the chosen strain selection strategy. It will also confirm the physiological effectiveness of the proposed mechanisms in, for example, a wider population of patients suffering immune disorders, such as Inflammatory Bowel Diseases (IBD) and Irritable Bowel Syndrome (IBS), as well as other gastrointestinal infection diseases, cancers and allergies.

Acknowledgements The authors thank Hariet Coleman for revising and correcting the English language. This work was financially supported by the Science Committee of Syndifrais and the Centre National Interprofessionnel de l'Économie Laitière (CNIEL). F.C. received a grant from CNIEL.

\section{References}

Adams MC, Huang Y (2003) Probiotic Propionibacterium jensenii 702, PatentWO2004001 022-A1

Adams MC, Huang Y (2008) Probiotic Propionibacterium, Patent US 07427397

Adams MC, Lean ML, Hitchick NC, Beagley KW (2005) The efficacy of Propionibacterium jensenii 702 to stimulate a cellmediated response to orally administered soluble Mycobacterium tuberculosis antigens using a mouse model. Lait 85:75-84

Alvarez S, Medicini M, Vintini E, Oliver G, De Ruiz Holgado AP, Perdigon G (1996) Effect of the oral administration of Propionibacterium acidi-propionici on IgA levels and on the prevention of enteric infection in mice. Microbiol Alim Nut 14:237-243

Andresen L, Hansen KA, Jensen H, Pedersen SF, Stougaard P, Hansen HR, Jurlander J, Skov S (2009) Propionic acid secreted from propionibacteria induces NKG2D ligand expression on human-activated T lymphocytes and cancer cells. J Immunol 183:897-906

Anonymous (2008) Scientific opinion of the panel on biological hazards on a request from EFSA on the maintenance of the QPS list of microorganisms intentionally added to food or feed. EFSA J 923:1-48

Bouglé D, Roland N, Lebeurrier F, Arhan P (1999) Effect of propionibacteria supplementation on fecal bifidobacteria and segmental colonic transit time in healthy human subjects. Scand J Gastroenterol 34:144-148 
Bouglé D, Vaghefi-Vaezzadeh N, Roland N, Bouvard G, Arhan P, Bureau F, Neuville D, Maubois J-L (2002) Influence of short-chain fatty acids on iron absorption by proximal colon. Scand J Gastroenterol 37:1008-1011

Cherbut C, Ferrier L, Roze C, Anini Y, Blottière H, Lecannu G, Galimiche JP (1998) Short-chain fatty acids modify colonic motility through nerves and polypeptide YY release in the rat. Am J Physiol Gastrointest Liver Physiol 275:G1415-G1422

Churruca I, Fernandez-Quintela A, Portillo MP (2009) Conjugated linoleic acid isomers: differences in metabolism and biological effects. Biofactors 35:105-111

Collado MC, Jalonen L, Meriluoto J, Salminen S (2006) Protection mechanism of probiotic combination against human pathogens: in vitro adhesion to human intestinal mucus. Asia Pac J Clin Nutr 15:570-575

Collado MC, Meriluoto J, Salminen S (2007a) Development of new probiotics by strain combinations: Is it possible to improve the adhesion to intestinal mucus? J Dairy Sci 90:2710-2716

Collado MC, Meriluoto J, Salminen S (2007b) In vitro analysis of probiotic strain combinations to inhibit pathogen adhesion to human intestinal mucus. Food Res Int 40:629-636

Collado MC, Meriluoto J, Salminen S (2007c) Role of commercial probiotic strains against human pathogen adhesion to intestinal mucus. Lett Appl Microbiol 45:454-460

Collado MC, Meriluoto J, Salminen S (2008) Adhesion and aggregation properties of probiotic and pathogen strains. Eur Food Res Technol 226:1065-1073

Cutting W, Read G, Cords H (1962) Preliminary studies on the chemical nature of propionin. Stanford Med Bull 20:156-162

de Vaux A, Morrison M, Hutkins RW (2002) Displacement of Escherichia coli O157:H7 from rumen medium containing prebiotic sugars. Appl Environ Microbiol 68:519-524

de Vrese M, Stegelmann A, Richter B, Fenselau S, Laue C, Schrezenmeir J (2001) Probioticscompensation for lactase insufficiency. Am J Clin Nutr 73:421S-429S

Dherbecourt J, Maillard MB, Catheline D, Thierry A (2008) Production of branchedchain aroma compounds by Propionibacterium freudenreichii: links with the biosynthesis of membrane fatty acids. J Appl Microbiol 105:977-985

Dherbecourt J, Falentin H, Jardin J, Maillard MB, Bagliniere F, Barloy-Hubler F, Thierry A (2010) Identification of a secreted lipolytic esterase in Propionibacterium freudenreichii, a ripening process bacterium involved in Emmental cheese lipolysis. Appl Environ Microbiol 76:1181-1188

Downes J, Wade WG (2009) Propionibacterium acidifaciens sp. nov., isolated from the human mouth. Int J Syst Evol Microbiol 59:2778-2781

El-Nezami H, Kankaanpaa P, Salminen S, Ahokas J (1998) Ability of dairy strains of lactic acid bacteria to bind a common food carcinogen, aflatoxin B-1. Food Chem Toxicol 36:321-326

El-Nezami H, Mykkanen H, Kankaanpaa P, Salminen S, Ahokas J (2000a) Ability of Lactobacillus and Propionibacterium strains to remove aflatoxin B-1 from the chicken duodenum. J Food Prot 63:549552

El-Nezami H, Mykkanen H, Kankaanpaa P, Suomalainen T, Salminen S, Ahokas J (2000b) Ability of a mixture of Lactobacillus and Propionibacterium to influence the faecal aflatoxin content in healthy Egyptian volunteers: a pilot clinical study. Biosci Microflora 19:41-45

El-Nezami HS, Chrevatidis A, Auriola S, Salminen S, Mykkanen H (2002) Removal of common Fusarium toxins in vitro by strains of Lactobacillus and Propionibacterium. Food Addit Contam 19:680-686

El-Nezami HS, Polychronaki NN, Ma J, Zhu HL, Ling WH, Salminen EK, Juvonen RO, Salminen SJ, Poussa T, Mykkanen HM (2006) Probiotic supplementation reduces a biomarker for increased risk of liver cancer in young men from Southern China. Am J Clin Nutr 83:1199-1203

Emenaker NJ, Basson MD (1998) Short chain fatty acids inhibit human (SW1116) colon cancer cell invasion by reducing urokinase plasminogen activator activity and stimulating TIMP-1 and TIMP-2 activities, rather than via MMP modulation. J Surg Res 76:41-46

FAO, WHO (2006) Probiotics in food: health and nutritional properties and guidelines for evaluation. FAO Food Nutr Pap

Foligné B, Nutten S, Grangette C, Dennin V, Goudercourt D, Poiret S, Dewulf J, Brassart D, Mercenier A, Pot B (2007) Correlation between in vitro and in vivo immunomodulatory properties of lactic acid bacteria. World J Gastroenterol 13:236-243

Fukushima A, Aizaki Y, Sakuma K (2009) Short-chain fatty acids induce intestinal transient receptor potential vanilloid type 6 expression in rats and Caco-2 cells. J Nutr 139:20-25

Furuichi K, Hojo K, Katakura Y, Ninomiya K, Shioya S (2006) Aerobic culture of Propionibacterium freudenreichii ET-3 can increase production ratio of 1, 4-dihydroxy-2-naphthoic acid to menaquinone. J Biosci Bioeng 101:464-470 
Furusawa E, Furusawa S, Cutting W (1965) Action mechanism of propionin against intracellular vaccinia multiplication and comparison with other agents. Med Pharmacol Exp Int J Exp Med 12:259-265

Furusawa E, Ramanathan S, Furusawa S, Woo YK, Cutting W (1967) Antiviral activity of higher plants and propionin on lymphocytic choriomeningitis infection. Proc Soc Exp Biol Med 125:234-239

Gratz S, El-Nezami H, Mykkanen H (2003) Probiotic bacteria retard the ex vivo absorption of aflatoxin B1 from chick duodenum. Toxicology 191:50

Gratz S, Mykkanen H, Ouwehand AC, Juvonen R, Salminen S, El-Nezami H (2004) Intestinal mucus alters the ability of probiotic bacteria to bind aflatoxin B-1 in vitro. Appl Environ Microbiol 70:63066308

Gratz S, Mykkanen H, El-Nezami H (2005) Aflatoxin B-1 binding by a mixture of Lactobacillus and Propionibacterium: in vitro versus ex vivo. J Food Prot 68:2470-2474

Halttunen T, Collado MC, El-Nezami H, Meriluoto J, Salminen S (2008) Combining strains of lactic acid bacteria may reduce their toxin and heavy metal removal efficiency from aqueous solution. Lett Appl Microbiol 46:160-165

Hartemink R, Rombouts FM (1999) Comparison of media for the detection of bifidobacteria, lactobacilli and total anaerobes from faecal samples. J Microbiol Methods 36:181-192

Haskard CA, El-Nezami HS, Kankaanpaa PE, Salminen S, Ahokas JT (2001) Surface binding of aflatoxin B-1 by lactic acid bacteria. Appl Environ Microbiol 67:3086-3091

Hatakka K, Ahola AJ, Yli-Knuuttila H, Richardson M, Poussa T, Meurman JH, Korpela R (2007) Probiotics reduce the prevalence of oral Candida in the elderly - a randomized controlled trial. J Dent Res 86:125-130

Hatakka K, Holma R, El-Nezami H, Suomalainen T, Kuisma M, Saxelin M, Polussa T, Mykkänen H, Korpela R (2008) The influence of Lactobacillus rhamnosus LC705 together with Propionibacterium freudenreichii ssp. shermanii JS on potentially carcinogenic bacterial activity in human colon. Int J Food Microbiol 128:406-410

Hervé C, Fondrevez M, Cheron A, Barloy-Hubler F, Jan G (2007) Transcarboxylase mRNA: a marker which evidences $P$. freudenreichii survival and metabolic activity during its transit in the human gut. Int J Food Microbiol 113:303-314

Hojo K, Yoda N, Tsuchita H, Ohtsu T, Seki K, Taketomo N, Murayama T, Iino H (2002) Effect of ingested culture of Propionibacterium freudenreichii ET-3 on fecal microflora and stool frequency in healthy females. Biosci Microflora 21:115-120

Holo H, Faye T, Brede DA, Nilsen T, Odegard I, Langsrud T, Brendehaug J, Nes IF (2002) Bacteriocins of propionic acid bacteria. Lait 82:59-68

Huang Y, Adams MC (2003) An in vitro model for investigating intestinal adhesion of potential dairy propionibacteria probiotic strains using cell line C2BBe1. Lett Appl Microbiol 36:213-216

Huang Y, Adams MC (2004) In vitro assessment of the upper gastrointestinal tolerance of potential probiotic dairy propionibacteria. Int J Food Microbiol 91:253-260

Huang Y, Kotula L, Adams MC (2003) The in vivo assessment of safety and gastrointestinal survival of an orally administered novel probiotic, Propionibacterium jensenii 702, in a male Wistar rat model. Food Chem Toxicol 41:1781-1787

Hubner RA, Houlston RS (2009) Folate and colorectal cancer prevention. Br J Cancer 100:233-239

Hugenholtz J, Hunik J, Santos H, Smid E (2002) Nutraceutical production by propionibacteria. Lait $82: 103-112$

Ibrahim F, Halttunen T, Tahvonen R, Salminen S (2006) Probiotic bacteria as potential detoxification tools: assessing their heavy metal binding isotherms. Can J Microbiol 52:877-885

Isawa K, Hojo K, Yoda N, Kamiyama T, Makino S, Saito M, Sugano H, Mizoguchi C, Kurama S, Shibasaki M, Endo N, Sato Y (2002) Isolation and identification of a new bifidogenic growth stimulator produced by Propionibacterium freudenreichii ET-3. Biosci Biotechnol Biochem 66:679-681

Jan G, Rouault A, Maubois J-L (2000) Acid stress susceptibility and acid adaptation of Propionibacterium freudenreichii subsp. shermanii. Lait 80:325-336

Jan G, Leverrier P, Pichereau V, Boyaval P (2001) Changes in protein synthesis and morphology during acid adaptation of Propionibacterium freudenreichii. Appl Environ Microbiol 67:2029-2036

Jan G, Belzacq AS, Haouzi D, Rouault A, Metivier D, Kroemer G, Brenner C (2002a) Propionibacteria induce apoptosis of colorectal carcinoma cells via short-chain fatty acids acting on mitochondria. Cell Death Differ 9:179-188

Jan G, Leverrier P, Proudy I, Roland N (2002b) Survival and beneficial effects of propionibacteria in the human gut: in vivo and in vitro investigations. Lait 82:131-144

Jan G, Lan A, Leverrier P (2007) Dairy propionibacteria as probiotics. In: Saarela M (ed) Functional dairy products, vol 2. Woodhead Publishing Ltd, Cambridge, UK, pp 165-194 
Kajander K, Korpela R (2006) Clinical studies on alleviating the symptoms of irritable bowel syndrome with a probiotic combination. Asia Pac J Clin Nutr 15:576-580

Kajander K, Hatakka K, Poussa T, Markkila M, Korpela R (2005) A probiotic mixture alleviates symptoms in irritable bowel syndrome patients: a controlled 6-month intervention. Aliment Pharmacol Ther 22:387-394

Kajander K, Krogius-Kurikka L, Rinttila T, Karjalainen H, Palva A, Korpela R (2007) Effects of multispecies probiotic supplementation on intestinal microbiota in irritable bowel syndrome. Aliment Pharmacol Ther 26:463-473

Kajander K, Myllyluoma E, Rajilic-Stojanovic M, Kyronpalo S, Rasmussen M, Jarvenpaa S, Zoetendal EG, De Vos WM, Vapaatalo H, Korpela R (2008) Clinical trial: multispecies probiotic supplementation alleviates the symptoms of irritable bowel syndrome and stabilizes intestinal microbiota. Aliment Pharmacol Ther 27:48-57

Kaneko T (1999) A novel bifidogenic growth stimulator produced by Propionibacterium freudenreichii. Biosci Microflora 18:73-80

Kaneko T, Mori H, Iwata M, Meguro S (1994) Growth stimulator for bifidobacteria produced by Propionibacterium freudenreichii and several intestinal bacteria. J Dairy Sci 77:393-404

Kekkonen RA, Kajasto E, Miettinen M, Veckman V, Korpela R, Julkunen I (2008a) Probiotic Leuconostoc mesenteroides ssp. cremoris and Streptococcus thermophilus induce IL-12 and IFN-gamma production. World J Gastroenterol 14:1192-1203

Kekkonen RA, Lummela N, Karjalainen H, Latvala S, Tynkkynen S, Jarvenpaa S, Kautiainen H, Julkunen I, Vapaatalo H, Korpela R (2008b) Probiotic intervention has strain-specific anti-inflammatory effects in healthy adults. World J Gastroenterol 14:2029-2036

Kirjavainen PV, El-Nezami HS, Salminen SJ, Ahokas JT, Wright PFA (1999) Effects of orally administered viable Lactobacillus rhamnosus GG and Propionibacterium freudenreichii subsp. shermanii JS on mouse lymphocyte proliferation. Clin Diagn Lab Immunol 6:799-802

Klaenhammer TR, Barrangou R, Buck BL, Azcarate-Peril MA, Altermann E (2005) Genomic features of lactic acid bacteria effecting bioprocessing and health. FEMS Microbiol Rev 29:393-409

Kouya T, Misawa K, Horiuchi M, Nakayama E, Deguchi H, Tanaka T, Taniguchi M (2007) Production of extracellular bifidogenic growth stimulator by anaerobic and aerobic cultivations of several propionibacterial strains. J Biosci Bioeng 103:464-471

Kuitunen M, Kukkonen K, Juntunen-Backman K, Korpela R, Poussa T, Tuure T, Haahtela T, Savilahti E (2009) Probiotics prevent IgE-associated allergy until age 5 years in cesarean-delivered children but not in the total cohort. J Allergy Clin Immunol 123:335-341

Kukkonen K, Savilahti E, Haahtela T, Juntunen-Backman K, Korpela R, Poussa T, Tuure T, Kuitunen M (2007) Probiotics and prebiotic galacto-oligosaccharides in the prevention of allergic diseases: a randomized, double-blind, placebo-controlled trial. J Allergy Clin Immunol 119:192-198

Kukkonen K, Savilahti E, Haahtela T, Juntunen-Backman K, Korpela R, Poussa T, Tuure T, Kuitunen M (2008) Long-term safety and impact on infection rates of postnatal probiotic and prebiotic (synbiotic) treatment: randomized, double-blind, placebo-controlled trial. Pediatrics 122:8-12

Lan A, Bruneau A, Philippe C, Rochet V, Rouault A, Herve C, Roland N, Rabot S, Jan G (2007a) Survival and metabolic activity of selected strains of Propionibacterium freudenreichii in the gastrointestinal tract of human microbiota-associated rats. Br J Nutr 97:714-724

Lan A, Lagadic-Gossmann D, Lemaire C, Brenner C, Jan G (2007b) Acidic extracellular pH shifts colorectal cancer cell death from apoptosis to necrosis upon exposure to propionate and acetate, major end-products of the human probiotic propionibacteria. Apoptosis 12:573-591

Lan A, Bruneau A, Bensaada M, Philippe C, Bellaud P, Rabot S, Jan G (2008) Increased induction of apoptosis by Propionibacterium freudenreichii TL133 in colonic mucosal crypts of human microbiota-associated rats treated with 1, 2-dimethylhydrazine. Br J Nutr 100:1251-1259

Langsrud T, Reinbold GW (1973) Flavor development and microbiology of Swiss cheese. A review. III. Ripening and flavor production. J Milk Food Technol 36:593-609

Lavillonniere F, Chajes V, Martin JC, Sebedio JL, Lhuillery C, Bougnoux P (2003) Dietary purified cis-9, trans-11 conjugated linoleic acid isomer has anticarcinogenic properties in chemically induced mammary tumors in rats. Nutr Cancer 45:190-194

Lee YK, El-Nezami H, Haskard CA, Gratz S, Puong KY, Salminen S, Mykkanen H (2003) Kinetics of adsorption and desorption of aflatoxin B-1 by viable and nonviable bacteria. J Food Prot $66: 426-430$

Lehto EM, Salminen S (1997) Adhesion of two Lactobacillus strains, one Lactococcus and one Propionibacterium strain to cultured human intestinal Caco-2 cell line. Biosci Microflora 16:1317 
Leverrier P, Dimova D, Pichereau V, Auffray Y, Boyaval P, Jan GL (2003) Susceptibility and adaptive response to bile salts in Propionibacterium freudenreichii: physiological and proteomic analysis. Appl Environ Microbiol 69:3809-3818

Leverrier P, Vissers JPC, Rouault A, Boyaval P, Jan G (2004) Mass spectrometry proteomic analysis of stress adaptation reveals both common and distinct response pathways in Propionibacterium freudenreichii. Arch Microbiol 181:215-230

Leverrier P, Fremont Y, Rouault A, Boyaval P, Jan G (2005) In vitro tolerance to digestive stresses of propionibacteria: influence of food matrices. Food Microbiol 22:11-18

Lind H, Sjogren J, Gohil S, Kenne L, Schnurer J, Broberg A (2007) Antifungal compounds from cultures of dairy propionibacteria type strains. FEMS Microbiol Lett 271:310-315

Lock AL, Corl BA, Barbano DM, Bauman DE, Ip C (2004) The anticarcinogenic effect of trans-11 18 : One is dependent on its conversion to cis-9, trans-11 CLA by Delta 9-desaturase in rats. J Nutr 134:2698-2704

Mantere-Alhonen S (1983) On the survival of a Propionibacterium freudenreichii culture during in vitro gastric digestion. Meijeritieteellinen Aikakauskirja 41:19-23

Mantere-Alhonen S (1995) Propionibacteria used as probiotics—a review. Lait 75:447-452

Matthews GM, Howarth GS, Butler RN (2007) Short-chain fatty acid modulation of apoptosis in the Kato III human gastric carcinoma cell line. Cancer Biol Ther 6:1051-1057

McIntosh FM, Shingfield KJ, Devillard E, Russell WR, Wallace RJ (2009) Mechanism of conjugated linoleic acid and vaccenic acid formation in human faecal suspensions and pure cultures of intestinal bacteria. Microbiology 155:285-294

Meile L, Le Blay G, Thierry A (2008) Safety assessment of dairy microorganisms: Propionibacterium and Bifidobacterium. Int J Food Microbiol 126:316-320

Michel C, Roland N, Lecannu G, Hervé C, Avice JC, Rival M, Cherbut C (2005) Colonic infusion with Propionibacterium acidipropionici reduces severity of chemically-induced colitis in rats. Lait 85:99111

Mitsuyama K, Masuda J, Yamasaki H, Kuwaki K, Kitazaki S, Koga H, Uchida M, Sata M (2007) Treatment of ulcerative colitis with milk whey culture with Propionibacterium freudenreichii. J Intest Microbiol 21:143-147

Mogensen G, Salminen S, O’Brien J, Ouwehand A, Holzapfel W, Shortt C, Fonden R, Miller G, Donohue D, Playne M, Crittenden R, Salvadori B, Zink R (2002) Inventory of microorganisms with a documented history of use in food, Bulletin of the IDF 10-19

Morata de Ambrosini V, Gonzalez S, Perdigon G, De Ruiz Holgado AP, Oliver G (1998) Immunostimulating activity of cell walls from lactic acid bacteria and related species. Food Agric Immunol 10:183-191

Mori H, Sato Y, Taketomo N, Kamiyama T, Yoshiyama Y, Meguro S, Sato H, Kaneko T (1997) Isolation and structural identification of bifidogenic growth stimulator produced by Propionibacterium freudenreichii. J Dairy Sci 80:1959-1964

Moussavi M, Adams MC (2010) An in vitro study on bacterial growth interactions and intestinal epithelial cell adhesion characteristics of probiotic combinations. Curr Microbiol 60:327-335

Myllyluoma E, Veijola L, Ahlroos T, Tynkkynen S, Kankuri E, Vapaatalo H, Rautelin H, Korpela R (2005) Probiotic supplementation improves tolerance to Helicobacter pylori eradication therapy-a placebo-controlled, double-blind randomized pilot study. Aliment Pharmacol Ther 21:1263-1272

Myllyluoma E, Ahlroos T, Veijola L, Rautelin H, Tynkkynen S, Korpela R (2007a) Effects of antiHelicobacter pylori treatment and probiotic supplementation on intestinal microbiota. Int $\mathrm{J}$ Antimicrob Agents 29:66-72

Myllyluoma E, Kajander K, Mikkola H, Kyronpalo S, Rasmussen M, Kankuri E, Sipponen P, Vapaatalo $\mathrm{H}$, Korpela R (2007b) Probiotic intervention decreases serum gastrin-17 in Helicobacter pylori infection. Digest Liver Dis 39:516-523

Myllyluoma E, Ahonen AM, Korpela R, Vapaatalo H, Kankuri E (2008) Effects of multispecies probiotic combination on Helicobacter pylori infection in vitro. Clin Vaccine Immunol 15:14721482

Niderkorn V, Boudra H, Morgavi DP (2006) Binding of Fusarium mycotoxins by fermentative bacteria in vitro. J Appl Microbiol 101:849-856

Okada Y, Hokari R, Kato S, Mataki N, Okudaira K, Takebayashi K, Matsunaga H, Tsuzuki Y, Komoto S, Watanabe C, Kawaguchi A, Nagao S, Itoh K, Miura S (2006a) 1.4-dihydroxy-2-naphthoic acid (DHNA) shows anti-inflammatory effect on NSAID-induced colitis in IL-10-knockout mice through suppression of inflammatory cell infiltration and increased number of Genus Bifidobacterium. Gastroenterology 130:A313 
Okada Y, Tsuzuki Y, Miyazaki J, Matsuzaki K, Hokari R, Komoto S, Kato S, Kato S, Kawaguchi A, Nagao S, Itoh K, Watanabe T, Miura S (2006b) Propionibacterium freudenreichii component 1.4dihydroxy-2-naphthoic acid (DHNA) attenuates dextran sodium sulphate induced colitis by modulation of bacterial flora and lymphocyte homing. Gut 55:681-688

Orla-Jensen O (1909) Die hauptlinien des natürlichen bakteriensystems, The main lines of the natural bacterial system. Zentralbl Bakteriol 22:305-346

Ouwehand AC, Tolkko S, Kulmala J, Salminen S, Salminen E (2000) Adhesion of inactivated probiotic strains to intestinal mucus. Lett Appl Microbiol 31:82-86

Ouwehand AC, Lagstrom H, Suomalainen T, Salminen S (2002a) Effect of probiotics on constipation, fecal azoreductase activity and fecal mucin content in the elderly. Ann Nutr Metab 46:159-162

Ouwehand AC, Suomalainen T, Tolkko S, Salminen S (2002b) In vitro adhesion of propionic acid bacteria to human intestinal mucus. Lait 82:123-130

Ouwehand AC, Salminen S, von Wright A, Ouwehand A (2004) The probiotic potential of propionibacteria, in: Lactic acid bacteria: Microbiology and functional aspects, 3 rd edition, revised and expanded. Marcel Dekker, New York, USA, pp 159-174

Perez-Chaia A, Zarate G (2005) Dairy propionibacteria from milk or cheese diets remain viable and enhance propionic acid production in the mouse cecum. Lait 85:85-98

Perez-Chaia A, Nader de Macias ME, Oliver G (1995) Propionibacteria in the gut: effect on some metabolic activities of the host. Lait 75:435-445

Perez-Chaia A, Zarate G, Oliver G (1999) The probiotic properties of propionibacteria. Lait 79:175-185

Pohjavuori E, Viljanen M, Korpela R, Kuitunen M, Tiittanen M, Vaarala O, Savilahti E (2004) Lactobacillus GG effect in increasing IFN-gamma production in infants with cow's milk allergy. J Allergy Clin Immunol 114:131-136

Rainio A, Vahvaselka M, Suomalainen T, Laakso S (2001) Reduction of linoleic acid inhibition in production of conjugated linoleic acid by Propionibacterium freudenreichii ssp. shermanii. Can J Microbiol 47:735-740

Rainio A, Vahvaselka M, Suomalainen T, Laakso S (2002) Production of conjugated linoleic acid by Propionibacterium freudenreichii ssp. shermanii. Lait 82:91-101

Ramanathan S, Furusawa E, Read G, Cutting W (1965) Isolation and activity of propionin A an antiviral polypeptide from propionibacteria. Chemotherapy 10:197-198

Ramanathan S, Read G, Cutting W (1966) Purification of propionin, an antiviral agent from propionibacteria. Proc Soc Exp Biol Med 123:271-273

Ramanathan S, Olynec C, Cutting W (1968) Antiviral principles of Propionibacteriaisolation, activity of Propionins B, C. Proc Soc Exp Biol Med 129:73-77

Ramanathan S, Furusawa E, Yee H, Cutting WC (1973) Propionin B an anti viralprinciple of propionibacteria. Chemotherapy 19:16-21

Roland N, Bouglé D, Lebeurrier F, Arhan P, Maubois J-L (1998) Propionibacterium freudenreichii stimulates the growth of Bifidobacterium bifidum in vitro and increases fecal bifidobacteria in healthy human volunteers. Int Dairy J 8:587-588

Ruijschop RMAJ, Boelrijk AEM, Giffel MCT (2008) Satiety effects of a dairy beverage fermented with propionic acid bacteria. Int Dairy J 18:945-950

Sanders ME (2008) Probiotics: definition, sources, selection, and uses. Clin Infect Dis 46:S58-S61

Sarkar S, Misra AK (1998) Effect of feeding Propiono-Acido-Bifido (PAB) milk on the nutritional status and excretory pattern in rats and infants. Milchwissenschaft 53:666-668

Sarkar S, Misra AK (2002) Effect of feeding dietetic yoghurt on the nutritional status and excretory pattern in rats and infants. Egypt J Dairy Sci 30:63-73

Satomi K, Kurihara H, Isawa K, Mori H, Kaneko T (1999) Effects of culture-powder of Propionibacterium freudenreichii ET-3 on fecal microflora of normal adults. Biosci Microflora 18:27-30

Seki K, Nakao H, Umino H, Isshiki H, Yoda N, Tachihara R, Ohuchi T, Saruta H, Suzuki K, Mitsuoka T (2004) Effects of fermented milk whey containing novel bifidogenic growth stimulator produced by Propionibacterium on fecal bacteria, putrefactive metabolite, defecation frequency and fecal properties in senile volunteers needed serious nursing-care taking enteral nutrition by tube feeding. J Intest Microbiol 18:107-115

Shimotoyodome A, Meguro S, Hase T, Tokimitsu I, Sakata T (2000) Short chain fatty acids but not lactate or succinate stimulate mucus release in the rat colon. Comp Biochem Physiol A Mol Integr Physiol 125:525-531

Sidorchuk II, Bondarenko VM (1984) Selection of a biologically active mutant of Propionibacterium shermanii and the possibility of its use in complex therapy of enteral dysbacteriosis. J Hyg Epidemiol Microbiol Immunol 28:331-338 
Somkuti GA, Johnson TL (1990) Cholesterol uptake by Propionibacterium freudenreichii. Curr Microbiol 20:305-309

Stackebrandt E, Schumann P, Schaal KP, Weiss N (2002) Propionimicrobium gen. nov., a new genus to accommodate Propionibacterium lymphophilum (Torrey 1916) Johnson and Cummins 1972, 1057 (AL) as Propionimicrobium lymphophilum comb. nov. Int J Syst Evol Microbiol 52:1925-1927

Suomalainen T, Sigvart-Mattila P, Matto J, Tynkkynen S (2008) In vitro and in vivo gastrointestinal survival, antibiotic susceptibility and genetic identification of Propionibacterium freudenreichii ssp. shermanii JS. Int Dairy J 18:271-278

Suzuki A, Mitsuyama K, Koga H, Tomiyasu N, Masuda J, Takaki K, Tsuruta O, Toyonaga A, Sata M (2006) Bifidogenic growth stimulator for the treatment of active ulcerative colitis: a pilot study. Nutrition 22:76-81

Thiel A, Eikmanns B, Salminen S, Ouwehand AC (2004) In vitro adhesion of propionibacteria to human intestinal mucus. Ital J Food Sci 16:245-253

Thierry A, Maillard MB, Yvon M (2002) Conversion of L-leucine to isovaleric acid by Propionibacterium freudenreichii TL 34 and ITGP23. Appl Environ Microbiol 68:608-615

Thierry A, Maillard MB, Hervé C, Richoux R, Lortal S (2004a) Varied volatile compounds are produced by Propionibacterium freudenreichii in Emmental cheese. Food Chem 87:439-446

Thierry A, Richoux R, Kerjean JR (2004b) Isovaleric acid is mainly produced by Propionibacterium freudenreichii in Swiss cheese. Int Dairy J 14:801-807

Trinidad TP, Wolever TMS, Thompson LU (1999) Effects of calcium concentration, acetate, and propionate on calcium absorption in the human distal colon. Nutrition 15:529-533

Tuomola EM, Ouwehand AC, Salminen SJ (1999) Human ileostomy glycoproteins as a model for small intestinal mucus to investigate adhesion of probiotics. Lett Appl Microbiol 28:159-163

Uchida M, Mogami O (2005) Milk whey culture with Propionibacterium freudenreichii ET-3 is effective on the colitis induced by 2, 4, 6-trinitrobenzene sulfonic acid in rats. J Pharmacol Sci 99:329-334

Vahvaselka M, Laakso S (2010) Production of cis-9, trans-11-conjugated linoleic acid in camelina meal and okara by an oat-assisted microbial process. J Agric Food Chem 58:2479-2482

Vesterlund S, Karp M, Salminen S, Ouwehand AC (2006) Staphylococcus aureus adheres to human intestinal mucus but can be displaced by certain lactic acid bacteria. Microbiology 152:1819-1826

Viljanen M, Kuitunen M, Haahtela T, Juntunen-Backman K, Korpela R, Savilahti E (2005a) Probiotic effects on faecal inflammatory markers and on faecal IgA in food allergic atopic eczema/dermatitis syndrome infants. Pediatr Allergy Immunol 16:65-71

Viljanen M, Pohjavuori E, Haahtela T, Korpela R, Kuitunen M, Sarnesto A, Vaarala O, Savilahti E (2005b) Induction of inflammation as a possible mechanism of probiotic effect in atopic eczemadermatitis syndrome. J Allergy Clin Immunol 115:1254-1259

Vorobjeva LI, Khodjaev EY, Cherdinceva TA (1995) Antimutagenic and reactivative activities of dairy propionibacteria. Lait 75:473-487

Vorobjeva LI, Iljasova OV, Khodjaev EY, Ponomareva GM, Varioukhina SY (2001) Inhibition of induced mutagenesis in Salmonella typhimurium by the protein of Propionibacterium freudenreichii subsp. shermanii. Anaerobe 7:37-44

Vorobjeva L, Leverrier P, Zinchenko A, Boyaval P, Khodjaev E, Varioukhina S, Ponomareva G, Gordeeva E, Jan G (2004) Anti-stress activity of Propionibacterium freudenreichii: identification of a reactivative protein, Antonie van Leeuwenhoek. Int J Gen Mol Microbiol 85:53-62

Vorobjeva LI, Khodjaev EY, Vorobjeva NV (2008) Propionic acid bacteria as probiotics. Microb Ecol Health Dis 20:109-112

Wahle KWJ, Heys SD, Rotondo D (2004) Conjugated linoleic acids: Are they beneficial or detrimental to health? Prog Lipid Res 43:553-587

Wang LM, Lv JP, Chu ZQ, Cui YY, Ren XH (2007) Production of conjugated linoleic acid by Propionibacterium freudenreichii. Food Chem 103:313-318

Warminska-Radyko I, Laniewska-Moroz L, Babuchowski A (2002) Possibilities for stimulation of Bifidobacterium growth by propionibacteria. Lait 82:113-121

Wood HG, Eastbrook RW, Srera P (1981) Metabolic cycles in the fermentation of propionic acid bacteria, in: Current topics in cellular regulation. Academic, New York, USA, pp 255-287

Yamazaki S, Kano K, Ikeda T, Isawa K, Kaneko T (1998) Mechanistic study on the roles of a bifidogenetic growth stimulator based on physicochemical characterization. BBA-Gen Subjects 1425:516-526

Yamazaki S, Kano K, Ikeda T, Isawa K, Kaneko T (1999) Role of 2-amino-3-carboxy-1, 4naphthoquinone, a strong growth stimulator for bifidobacteria, as an electron transfer mediator for $\mathrm{NAD}(\mathrm{P})(+)$ regeneration in Bifidobacterium longum. BBA-Gen Subjects 1428:241-250 
Yokota A, Tamura T, Takeuchi M, Weiss N, Stackebrandt E (1994) Transfer of Propionibacterium innocuum Pitcher and Collins 1991 to Propioniferax gen. nov., as Propioniferax innocua comb. nov. Int J Syst Bacteriol 44:579-582

Zarate G, Perez Chaia A (2009) Dairy bacteria remove in vitro dietary lectins with toxic effects on colonic cells. J Appl Microbiol 106:1050-1057

Zarate G, Chaia AP, Gonzalez S, Oliver G (2000) Viability and beta-galactosidase activity of dairy propionibacteria subjected to digestion by artificial gastric and intestinal fluids. J Food Prot 63:12141221

Zarate G, Chaia AP, Oliver G (2002a) Some characteristics of practical relevance of the beta-galactosidase from potential probiotic strains of Propionibacterium acidipropionici. Anaerobe 8:259-267

Zarate G, De Ambrosini VIM, Chaia AP, Gonzalez SN (2002b) Adhesion of dairy propionibacteria to intestinal epithelial tissue in vitro and in vivo. J Food Prot 65:534-539 